Acta Theriologica 44 (1): 29-36, 1999.

PL ISSN 0001-7051

\title{
Histometry and surface area of the alimentary canal of Apodemus flavicollis
}

\author{
Bogdana WILCZYŃSKA
}

\begin{abstract}
Wilczyńska B. 1999. Histometry and surface area of the alimentary canal of Apodemus flavicollis. Acta Theriologica 44: 29-36.

The alimentary canals of five males weighing $31.5-42.8 \mathrm{~g}$ and five females 31.2-43.3 g - of Apodemus flavicollis (Melchior, 1834) were studied. Lengths of the alimentary canals segments were measured together with thicknesses of tissues forming their wall and the internal and external areas of the segments were then calculated. In stomach there is a proventriculus structured like an esophagus. The surface layer of epithelial cells becomes cornified (52\% of epithelial lamina thickness), which supports mechanical treatment of food. In the fundus of the stomach, there is a strongly-developed glandular layer (38\% of wall thickness). The internal area of small intestine dominates the digestive-absorptive area of alimentary canal $(70 \%)$. The large intestine is second largest segment in internal area $-22 \%$. The sizes of the alimentary canal, ie length and external and internal areas, are 11-16\% larger in females, which shows the female adjustment to reproduction. The relative value of digestive absorptive area $\left(\mathrm{mm}^{2} / \mathrm{g}\right)$ reaches $206.8 \mathrm{~mm}^{2} / \mathrm{g}$ (females) and $164.0 \mathrm{~mm}^{2} / \mathrm{g}$ (males). The size of the alimentary canal of $A$. flavicollis reflects an accomodation of the canal to the digestion and absorption of the animal diet rich in calories, especially of insects which constitute the main component of the diet.
\end{abstract}

Department of Vertebrate Zoology, Institute of Biology and Environment Protection, Nicholas Copernicus University, Gagarina 9, 87-100 Toruń, Poland; e-mail: wilczyn@biol.uni.torun.pl

Key words: Apodemus flavicollis, alimentary canal, histometry, surface area

\section{Introduction}

Anatomical background for assimilating energy is a key problem that defines capabilities of an organism to survive and reproduce (Weiner 1992, Derting and Noakes 1995). Snipes (1994) says that growth of energy needs results in growth of digestive-absorptive area and growth of food absorption effectiveness. Defining the relationship between the size of digestive absorptive area and the metabolic rate is not possible without morphometric data obtained at the microscopic level.

However, they fail to give the sizes of the mucosa in other segments of the alimentary canal. Weiner (1989) suggests launching quantitive studies on the real size of digestive-absorptive area with the area, including mucosal enlargement through folds and intestinal villi. Some research carried out on the alimentary canal of laboratory (Fischer and Parsons 1950, Permezel and Webling 1971) and 
wild-living (Barry 1976, 1977, Borkowska 1995) rodents gives the sizes of the internal area of small intestine.

Experimental studies, carried out on the rodents of Microtus and Peromyscus, which were fed on a diet containing different amount of fibre, show a relationship between intestinal length, its mass, number of goblet cells in intestinal epithelium and quality of diet and energetic needs of the organism (Golley 1960, Gross et al. 1985, Green and Millar 1987). To define the anatomical basis of its role in storing, processing and assimilating food, both histological and anatomical methods to calculate the digestive-absorptive area were used and proportions between particular alimentary canals segments were shown. Morphometrical studies on the alimantary canal of $A$. flavicollis took place. Because of the type of its diet, A. flavicollis belongs to the omnivorous. In the diet of the species seeds, fruit, fungi, and green plant parts are dominant, with the considerable $62.8 \%$ proportion of insects in the summer food (Obrtel 1973, 1974). The results obtained this way will make it possible to show if and to what extent the diet affects the thickness of the tissues building up the wall of the segments in the canal, the size of the structures of the mucosa (folds and villi) as well as the internal surface area. The size of the digestive-absorptive area variously decides about the effectiveness of absorbing nutritious elements.

\section{Material and methods}

Alimentary canals of five males and five females of A. flavicollis were studied. Their body weight was between $31.5-42.8 \mathrm{~g}$ (males) and $31.2-43.3 \mathrm{~g}$ (females). After cutting specimens and fixing alimentary canals ( $10 \%$ formalin), the following segments were later analysed separately: oesophagus; stomach (separating proventriculus, fundus and pylorus); duodenum, jejunum and ileum in the small intestine; caecum, colon and rectum in the large intestine. The small intestine was distinguished on the basis of the histological analysis (wall thickness, height, diameter and density of villi $/ \mathrm{mm}^{2}$ ) of slices at constant distance of $200 \mu \mathrm{m}$. The proportion of the duodenum was $12 \%$, jejunum $54 \%$, and ileum $34 \%$ of total small intestine. The large intestine was distinguished into three segments, ie caecum, colon, and rectum (Snipes 1982, 1994). The proportion of the caecum was $27 \%$, colon $15 \%$, and rectum $58 \%$ of total large intestine.

From each segment I chose sections placed at constant distances, ie $2 \mathrm{~mm}$ in oesophagus, duodenum and caecum, $3 \mathrm{~mm}$ in jejunum and ileum, $1.5 \mathrm{~mm}$ in stomach and $6 \mathrm{~mm}$ in rectum.

For microscopic study, I used a paraffin method to make histological specimens. Slices of 5-10 $\mu \mathrm{m}$ were stained in Delafield's hematoxiline and eosine using Mallory's method (Burck 1975). The slices were used to measure the thicknesses of the tissues forming the alimentary canal wall. The measurements were carried out with use of eyepiece micrometer $(8 \times)$, exact to $3.0 \mu \mathrm{m}$, multiplied $320 \times$ and $13.0 \mu \mathrm{m}$, multiplied $80 \times$. Along the alimentary canal, the following measurements were made: lamina epithelialis mucosae, lamina propria mucosae, and lamina muscularis mucosae (tunica mucosae), tela submucosa, tunica muscularis and tuinica adventitia or serosa. The measurements were carried out in the folds for each segment. I also counted the number of folds and measured their height.

To calculate the digestive-absorptive areas of the alimentary canals segments, their internal and external circumferences were measured. Both external and internal areas were defined as a product of segment length and circumference (external circumference for external area and internal circumference for internal area). This way the external area of each segment of the alimentary canal was 
measured, and only measurements of the oesophagus, stomach and large intestine were made for the internal area. In the parts of the small intestine, I calculated total mucosa in two stages; first I measured smooth internal circumference placed at the bottom of villi and then I calculated the active area of the villi, ie their side area, for $1 \mathrm{~mm}^{2}$ of smooth mucosa area. After adding up two values, I obtained the entire mucosa area of the segment. All the measurements were carried out individually for each segment and sample. The results of the measurements and calculations were presented as mean numbers with standard deviation. The significance of the differences was shown using Student's $t$-test, with $p \leq 0.05$ as statistically significant.

The anatomical jargon is used according to Stelmasiak (1979) and the histological jargon according to Wawrzyniak (1974). Any comparisons to the human alimentary canal are referred to Krstič (1991),

\section{Results}

\section{Anatomical and histological structure}

The wall of the alimentary canal consists of four mucosas: tunica mucosa (built from three laminas - lamina epithelialis mucosae, lamina propria mucosae and lamina muscularis mucosae), tela submucosa, tunica muscularis and tunica adventitia or serosa (Fig. 1).

The mucous membrane of the oesophagus is covered with stratified squamous epithelium which consists of two layers: external - peeling off and internal cellular. The thickness of both layers measured between folds is similar in value for males and females and does not exceed $12.0 \pm 1.19 \mathrm{~mm}$. Muscular membrane is the thickest layer building oesophagus wall which is built from two muscle layers: internal (circular) and external (longitudinal) and amounts to $50 \%$ of the

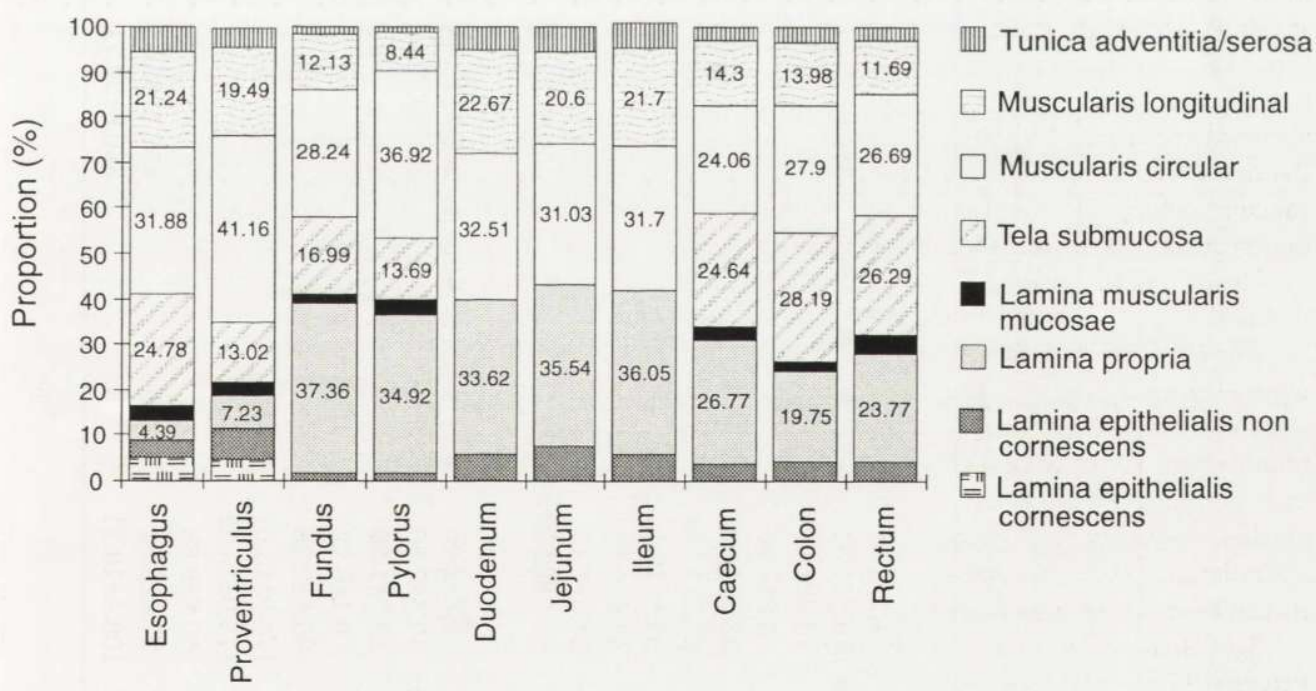

Fig. 1. The percentage proportion of layer thicknesses in wall structure of the segments of the alimentary canal (mean for males and females) of Apodemus flavicollis. 


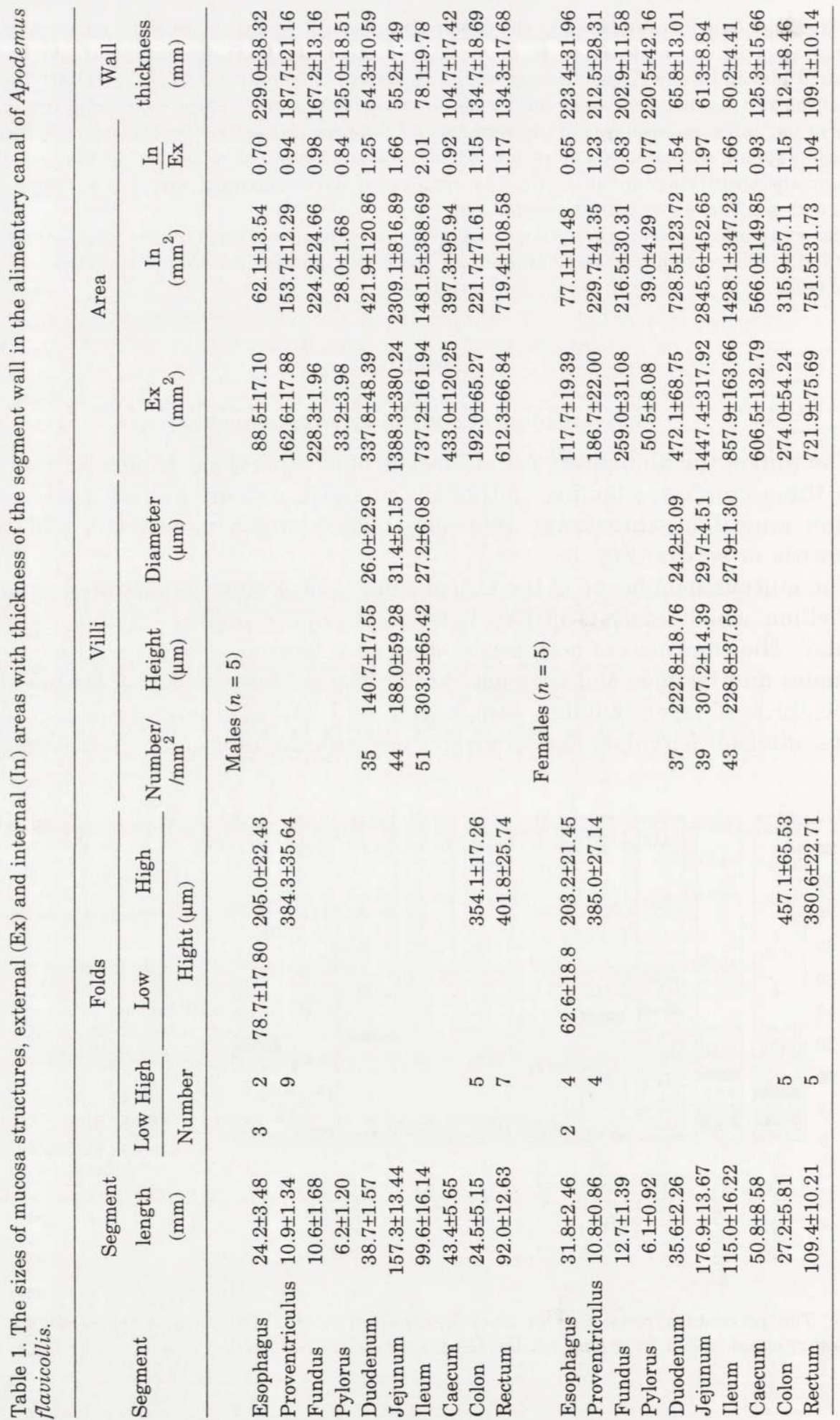


wall thickness (Fig. 1). The total thickness of the oesophagus wall is $229.0 \pm 38.32$ $\mu \mathrm{m}$ (males) and $223.4 \pm 31.96 \mu \mathrm{m}$ (females) (Table 1).

There are three parts in the stomach, ie proventriculus, fundus and pylorus. The proventriculus is the longest part. In males the length of the proventriculus is $10.9 \pm 1.34 \mathrm{~mm}$ and it is $10.8 \pm 0.86 \mathrm{~mm}$ in females. The proventriculus is $39 \%$ of total stomach length (males). The histological structure of the proventriculus part is like that in the oesophagus. I found considerable differences in the histological structure of the fundus. The mucous membrane is covered with simple columnar epithelium. The thickness of epithelial lamina is similar in both sexes and does not exceed $4.0 \mu \mathrm{m}$. The mucous lamina propria is full of glandulae gastricae propriae. The height of the glands is from $133.8 \pm 20.08 \mu \mathrm{m}$ (females) to $208.8 \pm 34.19 \mu \mathrm{m}$ (males). The muscular membrane is $37-40 \%$ of wall structure. The pylorus is the shortest part of the stomach $-6.0 \mathrm{~mm}$ on average, which is over $20 \%$ of total stomach's length. The height of epithelial lamina cells does not exceed $24.6 \pm 2.81 \mu \mathrm{m}$ for both sexes. The mucous lamina propria is covered with glandulae pyloricae. Their length reaches $151.4 \pm 21.14 \mu \mathrm{m}$ at the highest. Within the muscular membrane, the circular muscles are better developed. Their thickness is five times the thickness of the longitudinal muscles (Fig. 1).

The small intestine is the shortest segment of the alimentary canal and amounts to $57 \%$ of its total length (on average). The segment is divided into three parts: duodenum, jejunum and ileum. The jejunum is the longest part of the segment and amounts to $53 \%$ of its total length. The duodenum is $12 \%$ of the length and the ileum $-34 \%$. In all the parts, mucous, muscular and serosa membranes form the intestinal wall. Epithelial and proper laminas of mucosa form the mucous membrane. Cryptae intestinales occupy the whole width of the lamina and their height reaches $22.1 \pm 3.37 \mu \mathrm{m}$ (in the highest). The thickness of the layers building wall of the small intestine is similar in all its parts (Table 1). The total value of tissue thickness, which builds the intestinal wall, is highest in the ileum from $78.1 \pm 9.78 \mu \mathrm{m}$ (males) to $80.2 \pm 4.41 \mu \mathrm{m}$ (females) (Table 1).

The large intestine is divided into three parts: caecum, colon and rectum. The caecum is strongly developed ( $27 \%$ of total length of large intestine) and the rectum amounts to $58 \%$ length of large intestine (females). The muscular membrane is the thickest layer building the wall of the large intestine ( $40 \%$ of wall thickness) (Fig. 1).

\section{Structures of mucous membrane and its sizes}

In the oesophagus a well developed tunica mucosa along with the tela submucosa create 5-6 longitudinal folds. They can be divided into low folds, which reach $78.7 \pm 17.82 \mu \mathrm{m}$, and high folds of $205.0 \pm 22.43 \mu \mathrm{m}$ (males). They do little to increase the external area of the oesophagus, with the ratio of serosa to mucosa 1:0.70 (Table 1).

In the proventriculus, the tunica mucosa, along with the tela submucosa, also create longitudinal folds (from 4 in females to 9 in males) (Table 1). They are high 
$-385.0 \pm 27.14 \mu \mathrm{m}$, and slightly increase internal area, with the ratio of external to internal area 1:1.23 (females).

Folds in the large intestine slightly affect the size of the mucosa; their presence was observed both in the colon and the rectum. The tunica mucosa in the colon creates high folds in both sexes (ca 5), which reach $354.1 \pm 17.26 \mu \mathrm{m}$ in males and $457.1 \pm 65.53 \mu \mathrm{m}$ in females, and the ratio of mucosa to serosa is 1.15 . The rectum has from 5 (females) to 7 (males) folds with their height not exceeding $402.0 \mu \mathrm{m}$ for both sexes. The coefficient of mucosa development is 1.04 (females) and 1.17 (males) (Table 1).

The villi of the small intestine affect the size of the mucosa most. Their density for $1 \mathrm{~mm}^{2}$ of mucosa equals 36 in the duodenum, 42 in the jejunum and 47 in the ileum. They were highest in the jejunum of females $-307.2 \pm 14.39 \mu \mathrm{m}$, and lowest in the duodenum $140.7 \pm 17.55 \mu \mathrm{m}$ (males) and $222.8 \pm 18.76 \mu \mathrm{m}$ (females). The villi have the biggest diameter in the jejunum (in both sexes the value is similar - about $30.0 \mu \mathrm{m})$, the smallest in the duodenum $(26.0 \pm 2.29 \mu \mathrm{m})$ (Table 1$)$. The jejunum and ileum show the highest coefficient of mucosa development, where the ratio of internal area (extended by villi) to internal smooth area equals 2.01 while the lowest ratio is in the duodenum (1.55).

The total alimentary canal is longer in females $(576.3 \pm 86.44 \mathrm{~mm})$ while in males it is $507.4 \pm 76.1 \mathrm{~mm}$. The internal area of the alimentary canal is also longer in females and reaches $7197.9 \pm 1079.68 \mathrm{~mm}^{2}$ while in males the area reaches $6018.9 \pm 902.83 \mathrm{~mm}^{2}$ (Fig. 2).

Considerable differences between males and females $(p \leq 0.05)$ were observed only in the wall thickness of the pylorus, the surface of the internal area, and the relative value of the internal area $\left(\mathrm{mm}^{2} / \mathrm{g}\right)$.

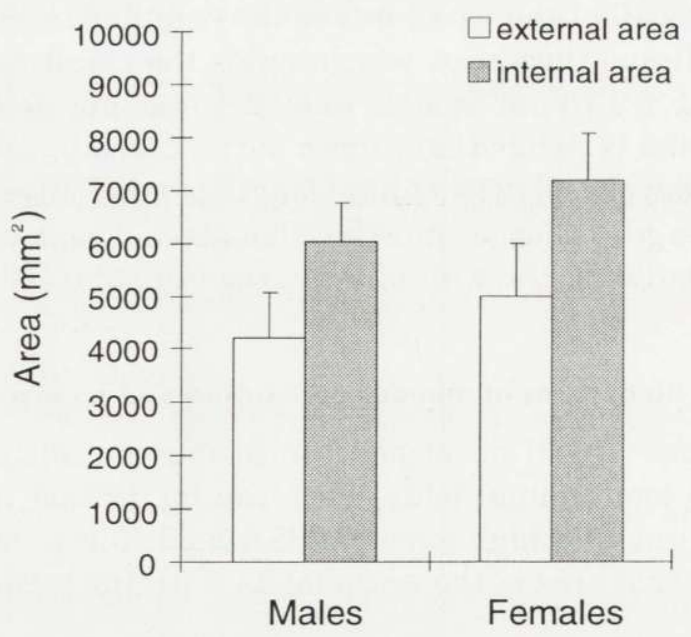

Fig. 2. Mean external and internal areas of the alimentary canal for five males and five females of Apodemus flavicollis. 


\section{Discussion}

In the oesophagus, which is responsible for transporting food to the stomach, the mucosa is the basic component of the wall, equal to $50 \%$ of the total thickness of wall. The surface epithelium of the oesophagus becomes cornified, which protects the mucosa against mechanical damage while swallowing hard food (eg insects), which make up $62.8 \%$ of the summer food of A. flavicollis (Obrtel 1973, 1974). A cornified oesophagus characterizes the oesophagus of animals feeding on hard food (Slocombe 1982, Przystalski 1987).

The presence of a proventriculus, the structure which is typical of the oesophagus, is also related to feeding on hard food, ie insects and seeds because it is in the proventriculus where mechanical forming of food takes place. On the other hand, I observed strong development of the glandular layer (38\% of wall thickness) and internal area (49\% of total thickness of digestive area in stomach) in the fundus, which shows that digestive processes are mainly placed in this part.

The mucosa of the alimentary canal in A. flavicollis creates longitudinal folds in the oesophagus, stomach and large intestine and villi in small intestine. The greatest number of the highest folds $(402.0 \mu \mathrm{m})$ is in the proventriculus $(9 \max )$ and rectum -7 . These structures increase the internal area by 1.23 times (proventriculus in females). Intestinal villi are finger-shaped and placed along intestinal long axis. The height of the villi and their diameter reach the highest values in the jejunum and ileum, more than doubling their absorptive area. The sizes of intestinal mucosa create sufficient conditions to digest and absorb food including animal proteins. In insectivorous species, ie Blarina brevicauda, Eptesicus fuscus, where animal food equals over $90 \%$ of diet composition and villi extend the area of jejunum and ileum from 4.3 to 8.0 times (Barry 1976).

The proportion of the small intestine in A. flavicollis is highest ( $70 \%$ of total internal area of the canal). The second largest segment is the large intestine (22\%), and the oesophagus is only $1 \%$ of total internal area of the canal.

The total digestive-absorptive area of the alimentary canal is 1.2 times bigger in females than males and equals $7197.9 \pm 1079.68 \mathrm{~mm}^{2}$ (Fig. 2). This value shows adapting females to reproduction. While pregnant and then lactating their offspring, females need extra amounts of energy, which means getting more food. The mass of the food taken in pregnancy increases by 32 to $50 \%$, and with lactating females by $133 \%$ in contrast with females reproductively inactive (Gębczyńska and Gębczyński 1971, Buchalczyk 1972).

The value of the coefficient of internal area of alimentary canal to body mass $\left(\mathrm{mm}^{2} / \mathrm{g}\right)$ is higher in females and equals $206.8 \mathrm{~mm}^{2} / \mathrm{g}$ compared to $164.0 \mathrm{~mm}^{2} / \mathrm{g}$ in males. The value of the coefficient is proved in the view of limiting metabolic level by the size of digestive-absorptive area, which represents the basis for optimalisation for sizes of the organ (Brody 1945, Gould 1966, Weiner 1989). 


\section{References}

Barry R. E. 1976. Mucosal, surface areas and villous morphology of the small intestine of small mammals: functional interpretations. Journal of Mammalogy 57: 273-290.

Barry R. E. 1977. Length and absorptive surface area apportionment of segments of the hindgut for eight species of small mammals. Journal of Mammalogy 58: 419-420.

Borkowska A. 1995. Seasonal changes in gut morpholgy of the striped field mouse (Apodemus agrarius). Canadian Journal of Zoology 73: 1095-1099.

Brody S. 1945. Bioenergetics and growth. Reinhold Publ. Co. New York: 1-1023.

Buchalczyk A. 1972. Seasonal variations in the activity of shrews. Acta Theriologica 17: 221-243.

Burck H-Ch. 1975. Technika histologiczna. Państwowy Zakład Wydawnictw Lekarskich, Warszawa: 1-234. [In Polish]

Derting T. L. and Noakes E. B. 1995. Seasonal changes in gut capacity in the white-footed mouse (Peromyscus leucopus) and meadow vole (Microtus pennsylvanicus). Canadian Journal of Zoology 73: $243-252$.

Fisher R. B. and Parsons D. S. 1950. The gradient of mucosal surface area in the small intestine of the rat. Journal of Anatomy 84: 272-282.

Gębczyńska Z. and Gębczyński M. 1971. Length and weight of the alimentary tract of root vole. Acta Theriologica 16: 359-369.

Golley F. B. 1960. Anatomy of the digestive tract of Microtus. Journal of Mammology 41: 89-99.

Gould S. J. 1966. Allometry and size in ontogeny and phylogeny. Biological Reviev 41: 587-640.

Green D. A. and Millar J. S. 1986. Changes in gut dimensions and capacity of Peromyscus maniculatus relative to diet quality and energy needs. Canadian Journal of Zoology 65: 2159-2162.

Gross J. E., Wang Z. and Wunder B. A. 1985. Effects of food quality and energy needs: Changes in gut morphology and capacity of Microtus ochrogaster. Journal of Mammalogy 66: 661-667.

Krstič R. V. 1991. Human microscopic anatomy. An atlas for students of medicine and biology. Springer-Verlag, Berlin: 1-616.

Obrtel R. 1973. Animal food of Apodemus flavicollis in a Lowland Forest. Zoologické Listy 22: 15-30.

Obrtel R. 1974. Comparison of animal food eaten by Apodemus flavicollis and Clethrionomys glareolus in a Lowland Forest. Zoologické Listy 23: 35-46.

Permezel N. C. and Webling D. D. 1971. The length and mucosal surface of the small and large gut in young rats. Journal of Anatomy 108: 295-296.

Przystalski A. 1987. [Morphometry of alimentary canal in some passerine birds (Passeriformes)]. Przegląd Zoologiczny 31: 139-157. [In Polish]

Slocombe R. F., Todhunter R. J. and Stick J. A. 1982. Quantitative ultrastructural anatomy of esophagus in different regions in the horse: Effects of alternate methods of tissue processing. American Journal of Veterinary Research 43: 1137-1142.

Snipes R. L. 1982. Anatomy of the caecum of the Gerbil Meriones unguiculatus (Mammalia, Rodentia, Cricetidae). Zoomorphology 100: 189-202.

Snipes R. L. 1994. Morphometric methods for determining surface enlergement at the microscopic level in the large intestine and their application. [In: The digestive system in mammals. Food, form and function. D. J. Chivers and P. Langer, eds]. Cambridge University Press, Cambridge: 446.

Stelmasiak M. (ed) 1979. Mianownictwo anatomiczne. Państwowy Zakład Wydawnictw Lekarskich, Warszawa: 1-330. [In Polish]

Wawrzyniak M. (ed) 1974. Polskie mianownictwo histologiczne. Państwowy Zakład Wydawnictw Lekarskich, Warszawa: 1-180. [In Polish]

Weiner J. 1989. Metabolic constraints to mammalian energy budgets. Acta Theriologica 34: 3-35.

Weiner J. 1992. Physiological limits to sustainable energy budgest in birds and mammals ecological implications. Trends in Ecology \& Evolution 11: 384-388.

Received 10 July 1997, accepted 12 October 1998. 